\title{
UPAYA MENCETAK PROFESIONALISME GURU IPA WILAYAH PESISIR MELALUI PELATIHAN LESSON STUDY DI KAMPUS CEMARA
}

\author{
Dyah Ayu Fajarianingtyas ${ }^{1)}$, Jefri Nur Hidayat ${ }^{2)}$ \\ ${ }^{1,2)}$ Prodi Pendidikan IPA FKIP Universitas Wiraraja \\ Email: Azrilarkan@gmail.com ${ }^{1)}$, jefri.nh@wiraraja.ac.id ${ }^{2)}$
}

\begin{abstract}
Abstrak
Permasalahan mitra/kelompok sasaran Pengabdian Kepada Masyarakat adalah sebagai berikut (1) Penyusunan perangkat pembelajaran IPA Terpadu belum dilakukan secara kolaboratif, dan (2) implementasi Lesson Study belum dilakukan berlandaskan prinsip-prinsip kolegalitas dan mutual learning secara akademis. Solusi yang ditawarkan untuk permasalahan mitra adalah pelatihan Lesson Study dalam kegiatan pembelajaran yang melibatkan sejumlah guru dan pakar pembelajaran. Metode yang ditawarkan untuk menyelesaikan persoalan mitra adalah menggunakan metode pendidikan masyarakat yaitu pelatihan penyusunan perangkat pembelajaran IPA Terpadu secara kolaboratif dan pendampingan implementasi Lesson Study berlandaskan prinsip-prinsip kolegalitas dan mutual learning secara akademis mencakup 3 (tiga) tahap kegiatan, yaitu merencanakan (plan) tahap pelaksanaan (do) yaitu pelaksanaan pembelajaran dan pengamatan oleh teman sejawat, dan tahap perefleksian (see) secara bersiklus dengan teman sejawat dan berkelanjutan. Pelaksanaan program pengabdian kepada masyarakat berupa pelatihan Lesson Study dapat disimpulkan berhasil yang ditunjukkan antara lain sebagai berikut: (1) respon positif dari HMP SECo adalah sebagai peserta pelatihan, guru IPA/alumni, dan dosen yang sesuai bidang keahlian Pendidikan IPA selama proses kegiatan pengabdian, serta (2) adanya peningkatan keterampilan/skill dalam menyusun perangkat pembelajaran IPA Terpadu secara kolaboratif melalui penerapan pembelajaran secara kolaboratif dan berkelanjutan berlandaskan prinsipprinsip kolegalitas dan mutual learning.
\end{abstract}

Kata Kunci: Lesson Study

\section{PENDAHULUAN}

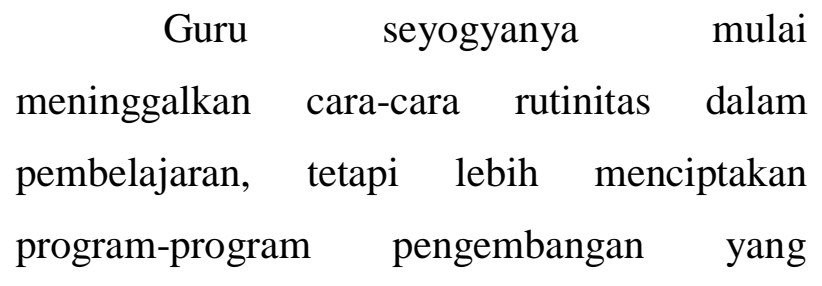
profesional. Upaya tersebut merupakan implikasi dari reformasi pendidikan dengan tujuan agar mampu mencapai peningkatan perolehan belajar siswa secara memadai. Program-program pengembangan profesi guru tersebut membutuhkan fasilitas yang dapat memberi peluang kepada mereka learning how to learn dan to learn about teaching. Masalah mitra/kelompok sasaran adalah berdasarkan hasil observasi diketahui bahwa sejumlah guru IPA di SMP/MTs Pesisir maupun sejumlah mahasiswa calon pendidik sebagai agen pembelajaran serta agen perubahan jarang mengkaji pembelajaran secara kolaboratif. Hal ini disebabkan lingkungan yang memicu pengkajian pembelajaran secara kolaboratif dan berkelanjutan berlandaskan prinsip-prinsip 
kolegalitas dan mutual learning belum terbangun secara akademis. Makna eksistensi kegiatan ini adalah dapat membangun pengkajian pembelajaran secara kolaboratif dan berkelanjutan berlandaskan prinsip-prinsip kolegalitas dan mutual learning secara akademis.

Upaya-upaya yang pernah dilakukan pihak lain adalah mengkaji pembelajaran secara individu tanpa melibatkan pihak lain.yang dapat memberikan masukan. Prinsipprinsip kolegalitas dan mutual learning dapat dibangun dari pihak eksternal seperti guru lain yang memiliki kompetensi yang relevan dengan keilmuan maupun dari pihak internal yaitu siswa yang menjadi subjek pembelajaran.

Tujuan kegiatan PKM adalah adanya peningkatan keterampilan/skill dalam menyusun perangkat pembelajaran IPA Terpadu secara kolaboratif melalui penerapan pembelajaran secara kolaboratif dan berkelanjutan berlandaskan prinsip-prinsip kolegalitas dan mutual learning (Perbaikan tata nilai masyarakat di bidang Pendidikan).

\section{MASALAH}

Permasalahan mitra/kelompok sasaran Pengabdian Kepada Masyarakat adalah sebagai berikut (1) Penyusunan perangkat pembelajaran IPA Terpadu belum dilakukan secara kolaboratif, dan (2) implementasi Lesson Study belum dilakukan berlandaskan prinsip-prinsip kolegalitas dan mutual learning secara akademis.

Solusi yang ditawarkan untuk permasalahan mitra adalah pelatihan Lesson Study dalam kegiatan pembelajaran yang melibatkan sejumlah guru dan pakar pembelajaran yang mencakup 3 (tiga) tahap kegiatan, yaitu merencanakan (plan) yaitu perencanaan pembelajaran dan penyiapan media pembelajaran, tahap pelaksanaan $(d o)$ yaitu pelaksanaan pembelajaran dan pengamatan oleh teman sejawat, dan tahap perefleksian (see) secara bersiklus dengan teman sejawat dan berkelanjutan (Tambupolon, 2014).

\section{METODE}

Metode yang ditawarkan untuk menyelesaikan persoalan mitra adalah menggunakan metode pendidikan masyarakat yaitu pelatihan penyusunan perangkat pembelajaran IPA Terpadu secara kolaboratif dan pendampingan implementasi Lesson Study berlandaskan prinsip-prinsip kolegalitas dan mutual learning secara akademis mencakup 3 (tiga) tahap kegiatan, yaitu merencanakan (plan) yaitu perencanaan pembelajaran dan penyiapan media pembelajaran, tahap pelaksanaan $(d o)$ yaitu pelaksanaan pembelajaran dan pengamatan oleh teman sejawat, dan tahap perefleksian (see) secara 
bersiklus dengan teman sejawat dan berkelanjutan.

$$
\text { Pelatihan dilakukan dengan }
$$

menggunakan latihan terbimbing. Latihan terbimbing dilakukan dengan memberikan permasalahan yang autentik untuk diamati dan dianalisis. Selanjutnya HMP SECo secara kelompok akan melakukan penyusunan perangkat pembelajaran IPA Terpadu secara kolaboratif dan selanjutnya menjadi guru model untuk melatih kompetensi guru meliputi profesional, pedagogi, sosial, dan kepribadian sebagai bagian dari profesionalisme guru dalam implementasi Lesson Study yang mencakup tahap plan, do, see di SMP/MTs sederajat Wilayah Pesisir.

Teknik Pengumpulan Data dilakukan menggunakan lembar observasi pada tahap plan, do, see. Teknik Analisis Data dilakukan secara deskriptif yang berisi sebagai suatu proses kolaboratif dari sekelompok guru untuk secara bersama-sama: (1) mengidentifikasi masalah pembelajaran yang dirasakan oleh guru (salah satu atau sekelompok guru) (2) merencanakan langkah-langkah pembelajaran (sebagai upaya pemecahan masalah yang terdidentifikasi),

(3) melaksanakan pembelajaran yang dilakukan oleh salah satu guru yang dipilih (disepakati), sementara guru lain mengobservasi proses pembelajaran, (4) mengevaluasi proses pembelajaran yang telah dilakukan (5) memperbaiki perencanaan pembelajaran berdasarkan hasil evaluasi (6) melaksanakan pembelajaran lagi, mengevaluasi kembali pembelajaran yang telah dilaksanakan, dan (8) membagi (menyebarluaskan) pengalaman dan temuan dari hasil evaluasi tersebut kepada guru lain..

Lokasi, waktu, dan durasi kegiatan pelatihan Lesson Study dilakukan di kampus cemara sebagai tempat penyusunan instrumen dan perangkat pembelajaran secara kolaboratif. Selanjutnya implementasi Lesson Study dilakukan di SMP/MTs wilayah pesisir. Waktu pelaksanaan mulai dari bulan Oktober sampai Mei 2018 dan durasi kegiatan 2xJam pelajaran masing-masing tahap plan, do, see.

\section{PEMBAHASAN}

Peserta pelatihan terdiri atas HMP SECo melakukan tahapan plan, do, see. Tahap perencanaan (plan) bertujuan untuk menghasilkan rancangan pembelajaran yang dapat membelajarkan siswa secara efektif serta membangkitkan partisipasi aktif siswa dalam pembelajaran. Pada tahap ini peserta pelatihan berkolaborasi bersama kelompok Lesson Study untuk berdiskusi menyiapkan perangkat pembelajaran sebagai berikut menyiapkan Silabus, menyiapkan RPP, menyiapkan LKS, menyiapkan soal tes, menyiapkan lembar observasi keterlaksanaan Lesson Study. Secara umum peserta pelatihan merencanakan 
pembelajaran yang berpusat pada peserta didik berbasis permasalahan di kelas, Tahapan Plan tampak pada Gambar 1 sebagai berikut.

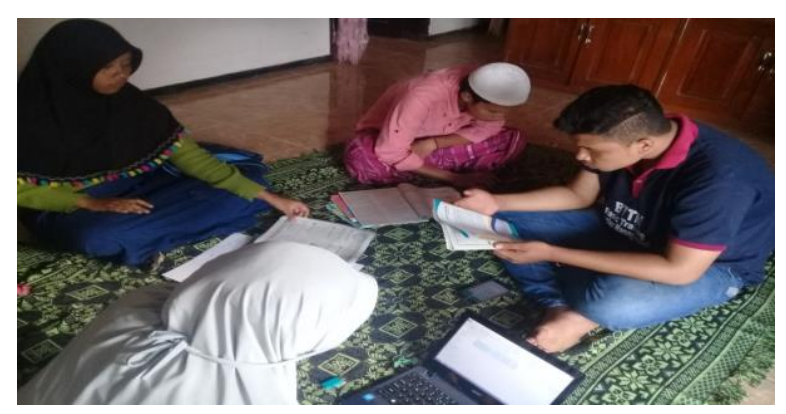

\section{Gambar 1. Tahapan Plan Lesson Study}

Tahap Do bertujuan berdasarkan rencana pembelajaran yang telah disusun, guru model melaksanakan pembelajaran di kelas yang telah ditentukan, sementara anggota lain bertindak sebagai observer, yang mengamati proses pembelajaran dengan menggunakan instrumen penelitian yang telah dikembangkan. Peserta pelatihan bertindak sebagai seorang guru IPA melaksanakan pembelajaran yang berpusat peserta didik. Sementara itu, peserta lain mengobservasi kegiatan belajar peserta didik, Tahapan Do tampak pada Gambar 2 sebagai berikut.

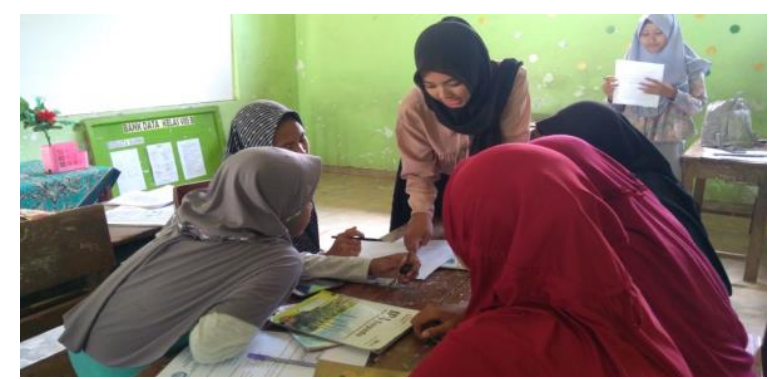

Gambar 2. Tahapan Do Lesson Study
Tahap See bertujuan agar setelah selesai pembelajaran, dilakukan postclass discussion atau kegiatan refleksi. Refleksi diikuti oleh semua anggota kelompok yang mengkaji hasil pengamatan setiap guru dan hasil rekaman proses pembelajaran. Secara kolaboratif, peserta pelatihan bersama guru IPA merefleksikan keefektifan pembelajaran dan saling belajar dengan prinsip kolegalitas, Tahapan See tampak pada Gambar 3 sebagai berikut.

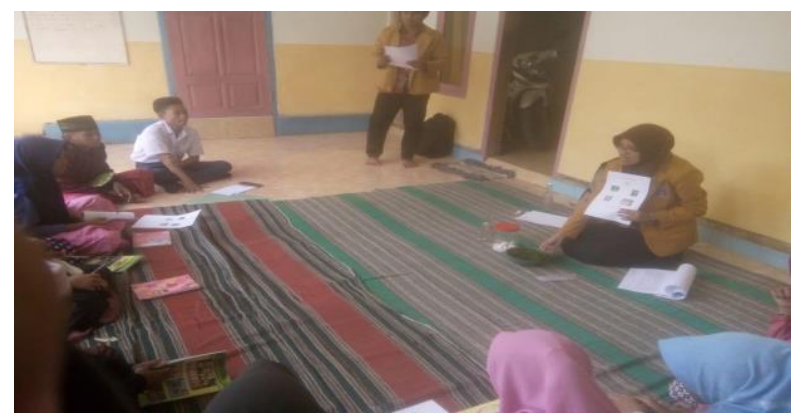

Gambar 3. Tahapan See Lesson Study

Keunggulan dalam kegiatan pelatihan Lesson Study adalah: (1). Peran mitra sangat mendukung dalam pelaksanaan kegiatan Program Pengabdian Masyarakat bagi pelaksana kegiatan; (2) Respon guru IPA maupun Dosen sebagai mitra kolaboratif; (3) Fasilitas Media Pembelajaran berupa video pembelajaran dan Power Point;

Kemampuan narasumber yang merupakan salah satu faktor pendukung program pelatihan.

Tingkat kesulitan pelaksanaan kegiatan (1) Setiap anggota kelompok lesson study 
harus memiliki komitmen untuk menyediakan waktu khusus dalam mewujudkan atau mengimplementasikan lesson study. Anggota kelompok ini biasanya menyelenggarakan pertemuan-pertemuan rutin baik satu hingga empat kali sebulan selama satu semester. Alokasi waktu dalam tahapan plan yang menyesuaikan jadwal akademik SMP/MTs di wilayah Pesisir; (2) penyusunan laporan kemajuan dari peserta pelatihan.

Hasil penelitian Mahmudi (2009) menyatakan bahwa meskipun semangat yang terkandung di dalam lesson study adalah saling belajar, namun mengingat budaya kita yang belum terbiasa dan tidak mudah untuk menerima kritik secara langsung, maka disarankan fokus evaluasi adalah pada bagaimana respon siswa terhadap pembelajaran yang dilaksanakan. Oleh karena itu, guru lain sebagai observer/pengamat diharuskan mendengarkan, mengamati, dan mencatat setiap respon siswa dengan rinci dan teliti. Diharapkan, guru model dapat menarik kesimpulan atas pembelajaran yang ia laksanakan, berdasarkan hasil evaluasi terhadap respon siswa dari hasil pengamatan guru lain dan dari hasil rekaman video. Dengan memperhatikan bagaimana siswa belajar, diharapkan guru yang bersangkutan menemukan kekurangan dan kelebihannya dalam mengajar.

\section{SIMPULAN}

Pelaksanaan program pengabdian kepada masyarakat berupa pelatihan Lesson Study dapat disimpulkan berhasil yang ditunjukkan antara lain sebagai berikut: (1) respon positif dari HMP SECo adalah sebagai peserta pelatihan, guru IPA/alumni, dan dosen yang sesuai bidang keahlian Pendidikan IPA selama proses kegiatan pengabdian, serta (2) adanya peningkatan keterampilan/skill dalam menyusun perangkat pembelajaran IPA Terpadu secara kolaboratif melalui penerapan pembelajaran secara kolaboratif dan berkelanjutan berlandaskan prinsip-prinsip kolegalitas dan mutual learning. Manfaat kegiatan adalah bagi peserta pelatihan maupun guru IPA adalah mengurangi keterasingan guru (dari komunitasnya) dalam perencanaan dan pelaksanaan pembelajaran dan perbaikannya, membantu guru untuk mengobservasi dan mengkritisi pembelajarannya, memperdalam pemahaman guru tentang materi pelajaran, cakupan dan urutan kurikulum, membantu guru memfokuskan bantuannya pada seluruh aktivitas belajar peserta didik, meningkatkan mutu guru dan mutu pembelajaran.

Rekomendasi yang dapat diberikan implementasi pelatihan Lesson Study adalah kegiatan pelatihan ini dapat berlangsung secara periodik untuk menunjang Prodi Pendidikan IPA. Keberlanjutan program dapat dilakukan oleh HMP SECo dalam kegiatan Science Club. 


\section{DAFTAR PUSTAKA}

Mahmudi, A. (2009). Mengembangkan Kompetensi Guru Melalui Lesson Study. Jurnal Forum Kependidikan, 28(2), 1-10.

Perry, R. R., \& Lewis, C. C. (2009). What is successful adaptation of lesson study in the US? Journal of Educational Change, 10(4), 365-391. https://doi.org/10.1007/s10833-008-90697

Susilo, H. (2008). Penelitian Tindakan Kelas. Malang: Banyumedia Publishing.

Tambupolon, S. (2014). Penelitian Tindakan Kelas Sebagai Pengembangan Profesi Pendidik dan Keilmuan. Jakarta: Erlangga. 